\title{
Meaningful Vocabularies Developed through Classroom Activities
}

\author{
Effy Mulyasari, Tatat Hartati \\ Universitas Pendidikan Indonesia, Bandung, Indonesia \\ Corresponding e-mail: effy@upi.edu
}

\begin{abstract}
Language can be learned subconsciously through various activities in classroom. Language learning of an infant is primarily achieved through listening and speaking, whereas reading would contribute after their visual-ability is welldeveloped. Vocabularies in printed form can be introduced to an infant as early as six months old. Reading capability is an indication of child's first insight into character and use of writing. This is a multi-case study, employing documentation analysis and unstructured interview techniques, based on three Early Childhood Education Program undergraduates participating in helping the development of kindergarten students' English vocabulary in Bandung, Indonesia. The three instructors focused merely on how to pronounce words but not in meaningful context. They also paid less attention in proper pronunciation in building vocabulary, and rarely check dictionary for proper pronunciation. They did not realize vocabulary mistakes can be sustained throughout the students' life. It would require at least three months for attempts to correct a meaning and pronunciation of a word. Therefore, to develop English vocabulary, an instructor or teacher should introduce them in meaningful context, and also in correct pronunciation through various methods such as listening to an audio, listening to teacher, watching a video, using pictures or printed media, repeating and practicing altogether.
\end{abstract}

Keywords: meaningful vocabularies, correct pronunciation, classroom activities

\section{INTRODUCTION}

This manuscript is based on three final projects of Early Childhood Education Program undergraduates in training English to kindergarten students in Bandung. These undergraduates are in the final years of their study to become kindergarten teacher; and would be termed instructor throughout the manuscript. They had assumption that such training is easy, not realizing that vocabulary need to taught in meaningful, joyful and in correct pronunciation.

At the beginning of the project, the instructors proposed theme and teaching materials, such as animals, fruits, numbers, or body parts. Although they prepared the intended vocabulary or words, they did not have definitive ideas on how to introduce them, moreover the integrated material in daily lesson plan. It was obvious that they needed to improve their skill in choosing themes, developing integrated program, choosing suitable materials according to the themes. They also needed to improve their skills in choosing relevant media that is meaningful to the children, and recognizing simple sentence pattern that can be applied in kindergarten students learning processes.

There are many methods in teaching kindergarten students, but in general it is implemented through playful activities. Improving their vocabulary can be done subconsciously. Variety of joyful activities should be designed to promote students' interest and lesson should be planned to be meaningful for the kindergarten students. We need to rethink what and how to teach to have a joyful learning (Puri, 2014)

English is the first foreign language in Indonesia. In general, Indonesian is kindergarten students' second language, since most of students in Bandung use Sundanese as their mother tongue. This mother tongue is depended on the region in Indonesia, as they are many other languages such as Java, Minang, Batak etc.

In learning productive skill, at school, kindergarten students need to be exposed to sounds as stimulus to new environment. Otto (2015: 285) supports that kindergarten capability in learning 
sound obtained by differentiating the similarity of sounds, and also differentiating of prefix and suffix. Kindergarten students would imitate without asking, whether it is correct or incorrect example. Thus, instructors should prepare intended words with appropriate supporting media and give correct pronunciation examples.

Based on initial discussion, the three instructors have limited skill in pronouncing the words in their teaching materials. The author had asked them to prepare and research the intended words. Previous research in 1995 has indicated that correcting a mispronounced word could take three months. Thus proper pronunciation is imperative prior teaching it to the kindergarten students. This would minimize incorrect word pronunciation and sense of its meaning by the kindergarten students, as they would copy and repeat them throughout their lives.

The main question of this research is how to teach English vocabulary to kindergarten students correctly, and in meaningful and joyful way.

This article is intended to find important aspects in preparing teaching English vocabulary in early childhood. It is expected to help teacher in preparing good lesson plan in introducing new English vocabulary to kindergarten students.

\section{METHOD}

This research used multi-case study, using unstructured interview and document analysis techniques (Burns, 1994). The author used multicase which is not based on sampling logic of multiple subjects in an experiment. This logic argues that each case must be selected and so that produces the similar results or on the contrary. This study is based on three cases.

Data collection were conducted in both qualitative and quantitative manners. Instructors' development of lesson plan is regarded as basic data on how they design a scenario in teaching and learning process in classroom. Discussion was conducted to check the instructors' capability in teaching new vocabularies. Lesson plan documents were asessed for their preparation. Interviews were also conducted to gather information on how the instructors' prepared and implement their lesson plan. The author refers to Stake (in Creswell, 1998) which offers triangulation protocol by Denzin in verification the data (1970) as data source, investigator, theory and methodological.

\section{LANGUAGE DEVELOPMENT IN EARLY CHILDHOOD}

Children will learn through reading and writing skill after they properly develop their visuals. Doman (1964, in Soderbergh, 1980), stated that an infant of six months old can be introduced to some vocabularies through printed words. Soderbergh (1981) also stated that reading is an indication of a child's first insight into the character and the use of writing.

Home and class environments will influence children language development. Children language development can be recognized from their knowledge of phonetics, semantics, syntactic, morphemes, and pragmatics. Preschool children are characterized by their rapid development of each aspect of language knowledge (Otto, 2015). Semantic knowledge of preschool students improve for both receptive words (written) and expressive words (spoken). As they develop, the arrangement of expression became more complex, thus they are able to communicate more precise.

The development of morphemes knowledge also contributes in creating message. Children's development in pragmatic knowledge is developed by using different spoken utterance in different situation. Children exploration in written language is also an evidence of their pragmatic knowledge development (Otto, 2015).

\section{FINDINGS AND DISCUSSIONS}

\subsection{Instructors Background}

All three instructors have common background, enrolled as undergraduate student in Early Childhood Education Program in Universitas Pendidikan Indonesia (UPI). They did not have special training in English, but eager to teach English to kindergarten students.

\subsection{Kindergarten Students Language Development}

Kindergarten student phonetic knowledge development has become understandable by parents (Allen and Marotz, 1994 in Otto, 2015).

Kindergarten students' vocabularies can reach 1500 words or more, which is adequate for conversation where they could understand most of implied meanings. At the age of five years old, they are able to compose basic sentence of five to seven words. 
They can communicate more complex ideas and has used noun and verb (Owen, 1998, 2001 in Otto, 2015). In using noun and verb, they can understand various different syntactic. Improvement of their morpheme knowledge is showed by implementing inflectional morpheme (verb tense, ownership, and comparison). Pragmatic knowledge of kindergarten students in spoken and written language is influenced by social situation and condition, and social interaction they had been through (Otto, 2015).

Otto (2015) also adds that children articulation in speech become more understandable, therefore easier for comprehension. In teaching English, a teacher needs to design a good lesson plan with special attention compared to teaching Indonesia Language. This is due to different pronunciation (sound) of letters in English words, as compared to exact sound of letters in Indonesian words. For example, 'satu' in Indonesian is read /satu/; whereas in English the written word 'one' is read $/ \mathrm{w} \Lambda \mathrm{n} /$. Madyawati (2016) explains that children language stages development start from one word (12-18 mos), two words (18-24 mos), more words (3-5 years). Thus, teaching English vocabularies should pay attention to how correctly pronounce words, because it will be imitated and repeated in practice by students.

\subsection{Teaching Materials Development}

In developing teaching materials the instructors need to consider theme of materials given in classroom. They need to realize the connection between taught vocabulary and the chosen theme. As stated in their lesson plan, they need to know the correct pronunciation. They need to answer several questions, such as: How they will develop the scenario in teaching and learning process? What kind of song to be used related to the vocabulary and the theme? What kinds of media that is suitable with the vocabulary to be taught? Which picture can support the teaching and learning process? How the vocabularies can be implemented in real life? What sentence patterns to be used? What story book to be read? The instructors need to repeat and practice the sentence pattern in order to help students in using it in their daily life.

A song adds a whole dimension to children's classes and make it easier for children to remember words and patterns and natural chunk of language (Paul, 2003). Through a song, children subconsciously learn vocabulary in fun way.
Therefore, a teacher should design teaching scenario that suitable song to the chosen theme.

Goodman, et al. (1979) stated that toddler learn to listen more rapidly than they learn to talk. The same strategy that has been well developed in listening must be applied in reading. It means that by exposing to listening, children will improve their capability in other language aspect, including in speaking and reading. Listening can be done through audio recorder, video recorder, or directly from a person. Other media can also be used in such as pictures, printed media, real things or artefacts. In evaluating teaching and learning objectives, instructors had to make a simple but attainable objective. Kindergarten student does not need to learn to read yet, therefore in learning vocabularies they don't have to learn by reading, but through listening and looking at the real object or representative picture or media. Instructors should write down questions that will be used, for clarity and evaluation purposes. Instructors need to improve the indicator used in evaluation, especially vocabularies that students need to master.

\subsection{Teaching Vocabulary}

There are some ways to teach vocabulary, such as: presenting vocabulary, using translation, illustrate meaning, explain meaning, highlight the form, and involve the learners (Thornbury, 2001). Meaningful vocabulary presentation could be done through translation, real things, pictures, actions/gestures, definitions, or situations.

In teaching a related set of words -related to theme and chosen objectives- a teacher has to decide how many words to present. This will depend on factors, such as (Thornbury, 2002):

a) level of learners (beginners, intermediate, advance),

b) learners' likely familiarity with words (learners may have met the words before even though are not part of their active vocabulary),

c) difficulty of item (whether abstract than concrete meaning, or they are difficult to pronounce),

d) 'teachability'- (whether they can easily explained or demonstrated)

e) items for production (in speaking and writing) or for recognition only (as in listening and reading). More time will be needed for the former.

The choice of the sequence of presentation, it could be

- Meaning first then form or

- Form first, then meaning 
For kindergarten students, it will be easier to learn new vocabulary through the first option. From the author experience involvement in preschool for four years, students can grasp better pronunciation and then they would participate in the given activities. In the first option the teacher holds up a picture of number one (1), and then say one. Sentence pattern used in asking the student to produce sounds or answering question in improving their vocabulary by asking 'what number is it?'. For other vocabularies the sentence pattern are adjusted to the vocabularies to be achieved. For example: 'what is it?, 'what do you see?, 'what is your favourite colour?' and so forth. It is expected to invite learners to actively participate practicing their new vocabularies by asking question using the given sentence pattern and answering using vocabularies as specified in the indicator to be reached.

Vocabulary development in early childhood education can be categorized to basic vocabulary which is not easy to change (Tarigan 1985 in Nurfauziah, 2013). The basic vocabulary refers to body parts such as head, shoulder, knee, toe, etc.; kinship, numbers, colors, animals, verbs, nouns, and so on.

The author experience in introducing vocabulary to her the two-years old daughter, that by unintendedly providing wrong answer to her question, it took almost three months to correct them. So, careful attention is needed to provide examples of new vocabulary.

\subsection{Kindergarten Curriculum}

For most kindergarten students, kindergarten curriculum is a shift time from home to school. For others, it is as a shift from a preschool to a formal school as an educational system. The curriculum of kidergarten which is related to elementary school can be varied. In some, kindergarten curriculum give stress on active students participation to prepare them entering elementary school (Otto, 2015).

\subsection{Examples of Material Development}

Theme in teaching vocabulary: Myself, My Home, My school, My Pets, My Hobby, In The Zoo Kinds of vocabulary: Numbers, Body Parts, Colors, Animals, Kindship, Verb, Noun.
Table 1. Instructor's pronunciation related to Body Parts

Theme: Myself

Subtheme: Body parts

\begin{tabular}{|c|c|c|c|}
\hline No & Word & Pronunciation & $\begin{array}{c}\text { Instructor's } \\
\text { pronunciation }\end{array}$ \\
\hline 1 & Head & $/ \mathrm{h} \mathrm{d} /$ & /hed/ \\
\hline 2 & Eye & /áy/ & /ai/ \\
\hline 3 & Mouth & /máw $\theta /$ & /mauth/ \\
\hline 4 & Ear & /Irr:/ & /ir/ \\
\hline 5 & Nose & /nóz/ & /nos/ \\
\hline 6 & Hand & /hǽnd/ & /hend/ \\
\hline 7 & Foot & $/ \mathrm{f} \mathrm{t} /$ & /fut/ \\
\hline 8 & One & $/ \mathrm{w} \Lambda \mathrm{n} /$ & /wan/ \\
\hline 9 & Two & /tú/ & $/ \mathrm{tu} /$ \\
\hline 10 & Three & /Orí:/ & /tri/ \\
\hline 11 & Four & $/ \mathrm{f} \mathrm{r} /$ & /for/ \\
\hline 12 & Five & /fáyv/ & /faiv/ \\
\hline 13 & Six & /síks/ & /sik/ \\
\hline 14 & Seven & $/ \mathrm{s} \mathrm{v} \mathrm{n} /$ & /seven/ \\
\hline 15 & Eight & / éit/ & /et/ \\
\hline 16 & Nine & /náyn/ & /nain/ \\
\hline 17 & Ten & $/ \mathrm{t} \mathrm{n} /$ & /tin/ \\
\hline 18 & Jumping & / $\Lambda \mathrm{mpin} /$ & /jamping/ \\
\hline 19 & Walking & /wókıı/ & /woking/ \\
\hline 20 & Reading & /rédin/ & /reding/ \\
\hline 21 & Singing & /sínin/ & /simging/ \\
\hline
\end{tabular}

Table 2. Instructor's pronunciation related to Animals

Theme: In the Zoo

Subtheme: Animals

\begin{tabular}{|c|c|c|c|}
\hline No & Word & Pronunciation & $\begin{array}{c}\text { Instructor's } \\
\text { pronunciation }\end{array}$ \\
\hline 1 & Monkey & / m jki/ & /mangki/ \\
\hline 2 & Frog & / frág/ & /frog/ \\
\hline 3 & Butterfly & /b t rflày/ & /baterflai/ \\
\hline 4 & Rabbit & /rǽbit/ & /rebit/ \\
\hline 5 & Duck & $/ \mathrm{d} \Lambda \mathrm{k} /$ & /dak/ \\
\hline 6 & Bird & /b rd/ & /bed/ \\
\hline 7 & Red & $/ \mathrm{r} \mathrm{d} /$ & /red/ \\
\hline 8 & White & /wáyt/ & /wait/ \\
\hline 9 & Black & /blǽk/ & /blek/ \\
\hline 10 & Blue & /blu:/ & /blu/ \\
\hline 11 & Yellow & /y lo/ & /yellow/ \\
\hline 12 & Green & /gri:n/ & /grin/ \\
\hline
\end{tabular}

\section{CONCLUSIONS}

An instructor needs to prepare complete lesson for kindergarten program. Consultations to other lecturers or supervisors are needed prior to teaching, to enrich instructors' ideas and to correct lesson plan and materials, and also to improve teaching 
materials for enjoyable learning process in classroom.

In planning a lesson, besides choosing vocabulary, an instructor should choose a theme that connects all teaching materials, which include, but not limited to, media, songs, storybook, sentence pattern.

It took three months to correct for unintended vocabulary mistake. Thus, careful planning is needed to create creative, interesting and joyful lesson.

\section{ACKNOWLEDGEMENTS}

The author would like to thank the three instructors for providing the opportunity to conduct this study. Through supervising them, the researcher felt that training a teacher is a never ending process. Thank you for trusting me in your training in early childhood education, and in finishing your program.

\section{REFERENCES}

Burns, R.B., (1994). Introduction to Research Methods. Melbourne: Longman Australia Pty Limited.

Creswell, J. W. (1998). Qualitative Inquiry and Research Design: Choosing among Five Traditions. Thousand Oaks: Sage Publications.

Goodman, K., Goodman, Y., \& Flores, B.. (1979). Reading in the Bilingual Classroom: Literacy and Biliteracy. System. Vol.9, N0.1, pp. 57-75.

Madyawati, L. (2016). Strategi Pengembangan Bahasa pada Anak. Jakarta: Prenadamedia Group.

Nurfaizah, L. (2013). Penggunaan Teknik Talking Stick dalam Meningkatkan Kosakata Bahasa Inggris Anak Usia Dini. Skripsi UPI FIP. Bandung: Tidak diterbitkan.

Paul, D. (2003). Teaching English to Children in Asia. Hong Kong: Pearson Education Asia Limited.

Otto, B. (2015). Perkembangan Bahasa pada Anak Usia Dini. Jakarta: Prenadamedia Group.

Soderbergh, R. (1980). Reading in Early Childhood. System, Vol. 8, pp 159-180.

Soderbergh, R. (1981). Early Reading as Language Acquisition. System, Vol. 9 No. 3, pp 207-213.

Thornbury, S. (2002). How to Teach Vocabulary. Essex: Pearson Education Limited.

Puri, Amita (2014) http://www.howtolearn.com/2014/11/how-tocreate-joyful-learning-in-the-classroom/ (access on Nov $8^{\text {th }} 2016$ ) 